\title{
Yaş meyve ve sebze ticaretinde tüccar ve komisyoncuların sosyal ağ analizi: Antalya ili örneği
}

Social network analysis of merchants and commissioners in fresh fruit and vegetable trade: the case of Antalya province

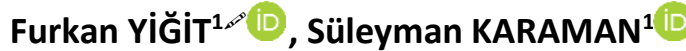

${ }^{1}$ Akdeniz Üniversitesi, Ziraat Fakültesi, Tarım Ekonomisi Bölümü, Antalya, Turkey.

MAKALE BILGISI / ARTICLE INFO

Makale tarihçesi / Article history:

DOI: $10.37908 /$ mkutbd.889471

Geliş tarihi /Received:02.03.2021

Kabul tarihi/Accepted:08.10.2021

\section{Keywords:}

Communication tools, social network, density, force-directed approach.

\footnotetext{
Corresponding author: S. KARAMAN

$\bowtie:$ skaraman@akdeniz.edu.tr
}

\section{Ö ZET / A B STR A C T}

Atıf / Citation: Yiğit F, Karaman S (2021) Yaş meyve ve sebze ticaretinde tüccar ve komisyoncuların sosyal ağ analizi: Antalya ili örneği. MKU. Tar. Bil. Derg. 26(3) : 736-745. DOI: 10.37908/mkutbd.889471 


\section{GíRiş}

Antalya' da seracılık sektörüne iklim koşullarının sağladığı avantajdan dolayı yapılan yatırımlar sebze üretimini, diğer bitkisel üretimlerle karşılaştırıldığında birinci sıraya yükseltmiştir. Diğer en fazla gelişme gösteren bitkisel üretim faaliyeti meyveciliktir. Antalya ilindeki yaş meyve ve sebze üretimindeki gelişmeler, Antalya Yaş Meyve ve Sebze Toptancı Hali'ni hem yurt içine hem de yurt dışına yönelik yaş meyve ve sebzenin pazarladığı önemli merkez haline getirmiştir. Toptancı Hali'ndeki ihracatçılar tarafından yaş meyve ve sebzeler büyük oranda Rusya Federasyonu, AB ülkeleri ve Irak'a ihraç edilmektedir (Anonim, 2020). Ayrıca, Türkiye'nin pek çok iline kış aylarında yaş meyve ve sebze gönderilmektedir. Toptancı Halinde 2019 yılında yaklaşık 823000 ton yaş meyve ve sebze işlem görmüştür. Bu işlem hacminin parasal değeri 1698 milyon TL'dir (Anonim, 2019). Dünya sebze üretiminde ilk sıralarda yer alan Türkiye'nin; küresel piyasalarda fiyat, kalite ve güvenilirlik açısından rekabet gücünün artırılması gerekmektedir (Kaya ve Bostan Budak, 2021).

Yaş sebze ve meyve piyasasında aktörler; üreticiler, komisyoncular ve tüccarlardır. Üreticiler, genellikle işgücünü üretime yönlendirdikleri ve piyasa bilgisine hâkim olmadıkları için, ürünün pazarlamasına yeterli zaman ayıramamaktadırlar. Bunların yanı sıra, yaş meyve ve sebze üreten işletmeler, çoğunlukla küçük ölçekli olup örgütlü bir yapıya sahip değildir. Bu yüzden, yaş meyve ve sebzeleri komisyoncular aracılığıyla pazarlamayı tercih etmektedir. Komisyoncular, kendilerine gönderilen ürünleri komisyon esasına göre satışını yapmaktadır. Tüccarlar, komisyoncudan satın aldığı ürünü yurtiçinde veya yurtdışında anlaştığı firmaya pazarlar ya da tüccarın iç pazarda kendisine ait diğer satış noktasına göndermektedir (Sayın ve ark., 2004; Tapkı ve ark., 2020). Komisyoncular ve tüccarlar, ürünün pazarlanması sürecinde ticari faaliyette bulundukları sosyal ağlardan faydalanırlar. Sosyal ağ, aktörler arasındaki ilişkilerin önemli olduğunu varsayar. Diğer yönden, sosyal ağlar ile kimlerin hangi bilgileri hangi iletişim araçlarını kullanarak kimlerle paylaştığı araştırılabilir (Gürsakal, 2009). Komisyoncular, üreticiler üzerinde çok geniş bir sosyal ağa sahiptir. Komisyoncu ve üreticiler arasındaki sosyal ağın oluşumunda yerel kültürel özellikler, siyasi, politik ve akraba ilişkilerinin önemli bir etken olduğu söylenebilir (Pan, 2007). Tüccarlar, yurtiçi ve yurtdışı olmak üzere belli bazı şehir ve ülkelerde ticari bağlantılar kurmakta ve ticari faaliyetlerini bu bağlantılara göre şekillendirmektedir. Tüccarların sosyal ağları, yurt içinde karşılıklı güven ve üye oldukları ticari örgütlere dayanırken yurt dışında ise ülkesel yakınlığa dayalı olduğu söylenebilir. Komisyoncu ve tüccarlar, sosyal ağ ilişkilerini kurarken yüz yüze, telefon ve internet aracılığıyla iletişim kurmaktadırlar. Yaş meyve sebze ticaretinde sosyal ağ kurarken kullanılan iletişim araçları fonksiyonları açısından farklılık gösterebilmektedir. İnternet, iletişim sürecini kolaylaştırarak yaş meyve ve sebze ticaretini destekleyen çeşitli avantajlar sunar. İnternet kullanımı hem bilgisayar hem de cep telefonlarılla gerçekleşmektedir. Cep telefonu yalnızca kişiler arası iletişim için değil, aynı zamanda yaş meyve ve sebze pazarlamasında ve multimedya kullanımı gibi çevrimiçi akıllı telefon faaliyetlerini ve diğer uygulamaları gerçekleştirmek için de kullanır (Leung, 2007; Demirtaş ve Kaya, 2018). Diğer yönden, cep telefonları sosyal iletişim sağlama aracı olarak kabul edilebilir (Przybylski ve ark., 2013). Bu çerçevede çalışmada, yaş meyve ve sebze ticaretinde iletişim araçlarının rolü nedir? sorusu araştırımaktadır. Yaş meyve ve sebze ticaretinde komisyoncu ve tüccarlar geleneksel pazarlama yöntemlerini bir yana bırakarak, hedef pazarlar için iletişim araçlarını kullanarak farklı ve özgün stratejiler oluşturmak durumundadır. Aksi durumda, halihazırdaki pazarları kaybetme durumu ile karşı karşıya kalınacak ve sektörün ulusal ekonomiye katkısı azalacaktır. Bunun için komisyoncu ve tüccarların sosyal ağlarının oluşumunda iletişim araçları kullanma durumu araştırılarak yaş meyve ve sebze pazarlama etkinliğinin arttırılmasına yönelik etkin iletişim kurabilme stratejileri geliştirilmesi hedeflenmektedir.

\section{MATERYAL ve YÖNTEM}

$\mathrm{Bu}$ çalışmanın ana materyalini, Antalya Büyükşehir Belediyesi Yaş Meyve ve Sebze Toptancı Hali'nde faaliyet gösteren tüccar ve komisyoncular ile yüz yüze yapılan anketlerden elde edilen veriler oluşturmaktadır. Yaş Meyve ve Sebze Toptancı Halinde 144 komisyoncu ve 319 tüccar bulunmaktadır. Araştırma için örnek kitlesi belirlenirken gayeli olarak seçilen 30 tüccar ve 30 komisyoncu ile 2017 yılında anket yapılmıştır. Hedef kitlenin temsili açısından araştırmalarda en az 30 birimlik bir örneğin normal dağılım gösterdiği kabul edilmektedir (Korum, 1981). Anket verileri, tanımlayıcı istatistikler, çizelgeler ve şekiller ile değerlendirilmiştir.

Araştırmada, yaş meyve ve sebze arz zincirinde yer alan komisyoncu ve tüccarların kullandığı iletişim araçları değerlendirilmiştir. Bu çerçevede, komisyoncu ve tüccarların yaş meyve ve sebze ticaretinde kullandıkları iletişim araçları ve kullanım düzeylerinin farklı olup olmadığı test edilmiştir. Tüccar ve komisyoncuların iletişim araçları ile gerçekleştirdikleri etkileşimler sosyal ağ analizi ile açıklanmaktadır. Sosyal ağ, sosyal olarak 
anlamlı ilişkiler yoluyla birbirine bağlanan birey veya gruptur (Wellman ve Berkowitz, 1988). Bu tür sosyal anlamlı ilişkilere örnek; aile, arkadaşlar veya güvene dayalı ilişkiler, tavsiye verme veya bilgi paylaşımı sayılabilir. Sosyal ağ, arkadaşlık, birlikte çalışma veya bilgi alışverişi gibi bir dizi sosyal ilişkiyle birbirine bağlanan bir grup kişidir (veya kuruluşlar veya diğer sosyal varlıklar).

Sosyal ağ analizi, sosyal ilişkileri düğümler ve bağlardan (ayrıca kenarlar, bağlantılar veya bağlantılar da denir) oluşan ağ teorisi olarak görür. Sosyal ağlarda, düğümler insanları veya kuruluşları temsil ederken, bağlantılar, iletişim modelleri, iş birlikleri veya kaynak değişimi gibi düğümler arasındaki ilişkileri temsil eder (Bodin ve Crona, 2009).

Sosyal ağ analizi ile tek yönlü bir ağ yapısı ortaya çıkmıştır. Ayrıca ağın görselleştirilmesinde Fruchterman ve Reingold düzeltmesi kullanılmıştır. Güç yönelimli (force-directed) bir yaklaşıma dayanan bu algoritma ile düğümler ağda en güçlü bağlantılarına yakın olarak konumlanmaktadır (Fruchterman ve Reingold, 1991). Güç yönelimli bir ağ, düğümleri aralarındaki bağlara göre dinamik olarak yerleştirir. Genel olarak, birlikte faaliyet gösteren insanlar birbirine yakın gösterilirken, ilişkisi olmayanlar daha uzakta gösterilir. Bu nedenle, güce yönelik ağ, kümeleri görüntülemek ve gruplar arasında iş birliği eksikliği için mükemmeldir. Sosyal ağlarının şekilleri UCINET Versiyon 6.364 ve Pajek Version 5.11 paket programlarıyla oluşturulmuştur (Borgatti ve ark., 2002, DeNooy ve ark., 2011).

Sosyal ağ teorisi, sosyal etkileşim modellerini anlamak için ağın yapısına göre bazı göstergeler ve kavramlar önermektedir. Bunlardan biri olan yoğunluk, sosyal ağ aktörleri arasında bilgiye erişim olasılığını tahmin eder ve etkileşimin etkisini değerlendirir. Bir ağda birbirine bağlı düğüm sayısı arttıkça, bütünlük artmakta ve nihai olarak yoğunluk artmaktadır (Scott, 2000). Yoğunluk, bir bağın ortalama gücüdür. Yoğunluk potansiyel olarak kullanılabilecek bağlantıların yüzde kaçının kullanıldığını göstermektedir (Tüzüntürk, 2012; Wasserman ve Faust, 1994). Sosyal ağ içinde gözlemlenen gerçek bağlantı sayısının dügüm sayısı ile gösterilen potansiyel bağlantı sayısına bölünmesiyle elde edilir (Butts, 2008).

(D) = yoğunluk, mevcut ilişkilerin sayısına eşittir.

$(I)=$ aktörler arasındaki olası ilişki sayıları (n.(n-1)).

$D=\frac{2 l}{n(n-1)} * 100$

(1)

\%100 yoğunluk tüm aktörlerin birbirine bağlı olduğunu gösterir iken \%0 yoğunluk, tüm aktörlerin birbiriyle bağlantısı olmadığını gösterir.

\section{BULGULAR ve TARTIŞMA}

Anket yapılan tüccarların \%44.4'ünün ve komisyoncuların \%39.7'sinin yaşı, $35-45$ yaş aralığındadır. Tüccarların \%22.2'si 55 yaşından büyük ve komisyoncuların \%28.2'si 45-55 yaş aralığındadır. Toptancı Haldeki tüccar ve komisyoncular büyük oranda ilköğretim ve lise mezunudur. Tüccarların yaklaşık \%78'i, komisyoncuların ise yaklaşık \%83'ü ilköğretim ve lise eğitim düzeyine sahiptir. Tüccarların \%22.2'si, komisyoncuların \%16.7'si üniversite mezunudur (Çizelge 1). Diğer bir çalışmada, komisyoncuların ortalama yaşı yaklaşık 40 olarak bulunmuştur. Ankete katılan komisyoncuların \%57.7'si $26-40, \% 42.3$ 'ü ise $40-55$ yaş sınırı arasındadır. Komisyoncuların \%30.8'i ilkokul, $\% 53.8$ 'i ortaöğretim, \%3.8'i yüksekokul ve \%11.5'i fakülte mezunudur (Yılmaz ve Yılmaz, 2002).

Çizelge 1. Tüccar ve komisyoncuların eğitim düzeyleri Table 1. Merchants and commissioners' education levels

\begin{tabular}{lcr}
\hline $\begin{array}{l}\text { Eğitim } \\
\text { Düzeyleri }\end{array}$ & $\begin{array}{r}\text { Tüccar } \\
(\%)\end{array}$ & $\begin{array}{r}\text { Komisyoncu } \\
\text { (\%) }\end{array}$ \\
\hline Illköğretim & 44.4 & 41.7 \\
Lise & 33.3 & 41.7 \\
Üniversite & 22.2 & 16.7 \\
Toplam & 100.0 & 100.0 \\
\hline
\end{tabular}

Tüccarların \%60.1'i yaş meyve ve sebze piyasasında 15 yıldan fazla deneyime sahiptir. Bu piyasa, özellikli olduğundan deneyimin ön planda olduğu açıktır. Bu yüzden, piyasa tecrübesi ve birikimi olan tüccarların kazançlarının yüksek olması beklenmektedir. Komisyoncular, üretici adına yaş meyve ve sebze pazarlayarak kazanç sağlamaktadır. Komisyoncuların \%51.6'sı 15 yıldan fazladır yaş meyve ve sebze pazarlamaktadır. Komisyoncular içerisinde 5 yıla kadar deneyim sahibi olanların oranı \%23.4'tür. Diğer yönden, tüccarlara göre 21 yıldan fazla deneyime sahip komisyoncu oranı daha düşüktür (Çizelge 2). Diğer bir araştırmada, komisyoncuların mesleki deneyim düzeylerinin çoğunlukla 1-10 yıl ve 11-20 yıl arasında olduğu, mesleki deneyimi $21-30$ yıl ile 30 yıl ve üzerinde bulunan komisyoncuların oranının düşük düzeyde olduğu tespit edilmiştir (Coşkun, 2014). 
Çizelge 2. Tüccar ve komisyoncuların faaliyet süreleri Table 2. Merchants and commissioners' activity periods

\begin{tabular}{lrr}
\hline Faaliyet Süreleri & Tüccar (\%) & Komisyoncu (\%) \\
\hline $1-5$ & 16.7 & 23.4 \\
$6-10$ & 11.1 & 8.3 \\
$11-15$ & 11.1 & 16.7 \\
$16-20$ & 27.8 & 44.7 \\
$21+$ & 33.3 & 6.9 \\
Toplam & 100.0 & 100.0 \\
\hline
\end{tabular}

\section{iletişim araçlarının kullanımı}

Tüccarlar ve komisyoncular, yaş meyve ve sebze ticari faaliyetlerini gerçekleştirirken iletişim araçlarını kullanmaktadırlar. Toptancı Halinde satış faaliyeti gerçekleştiren tüccarların \%89'u alıcılarla telefonla iletişim kurarken, \%34'ü internetten faydalanmaktadır.
Toptancı Hali'nde tüccarlar, üreticilerin mallarını pazarlayan komisyoncularla haberleşirken ise \%84'ü telefon kullanmaktadır ve $\% 28^{\prime} i$ yüz yüze görüşmeyi tercih etmektedir (Çizelge 3 ).

Illetişim araçları, internet ve telefonun yaş meyve ve sebze ticaretinde tüccarlara katkı düzeyi araştırılmıştır. Internet ve telefonun, tüccarların \%53'ü tarafından yeni müşteri bulmaları ve diğer ticari faaliyetlerini yürütmelerinde çok fazla katkı sağladığı ifade edilmiştir. Bunun yanı sıra az katkı sağlıyor düşüncesinde olanların oranı \%13'tür. Genel olarak değerlendirildiğinde tüccarların \%66'sının internet ve telefonun yaş meyve ve sebze ticaretinde katkısının olduğu kanaatindedir. Diğer yönden, tüccarların \%17'si ise telefon ve internetin hiç katkı sağlamadığı görüşündedir (Şekil 1).

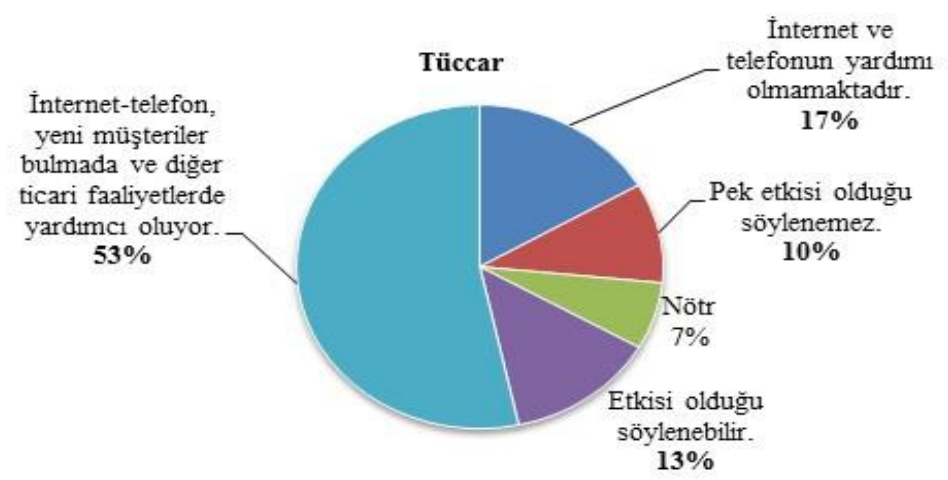

Şekil 1.iletişim araçlarının tüccarların ticari faaliyetlerine etkileri.

Figure 1. The effects of communication tools on merchants' business activities.

Toptancı Hali'nde yaş meyve ve sebze pazarlayan komisyoncuların \%67'si üreticilerle yüz yüze iletişim kurmakta, \%65'i telefonla haberleşmektedir (Çizelge 3). Komisyoncular, sürekli ürün getiren çiftçilerle telefon ile görüşerek piyasa ve fiyat bilgisi vererek hasat yapıp yapmaması konusunda bilgilendirmektedir. Ayrıca, üreticiler yaş meyve ve sebzelerini Toptancı Haline getirdiklerinde komisyoncularla yüz yüze görüşmektedir. Komisyoncular için telefonun üreticilerle görüşme ve diğer ticari faaliyetlere katkı düzeyi değerlendirilmiştir. Komisyoncuların \%47'si telefonun ticari faaliyetlerini yürütmede çok önemli katkısı olduğunu, \%7'si az etkisi olduğu görüşündedir. Genel olarak değerlendirildiğinde komisyoncuların \%54'ü telefonun olumlu katkı sağladığı düşüncesindedir. Komisyoncular, telefonu hem üreticilerle hem de tüccarlarla görüşmelerinde aktif olarak kullanmaktadır (Şekil 2). 


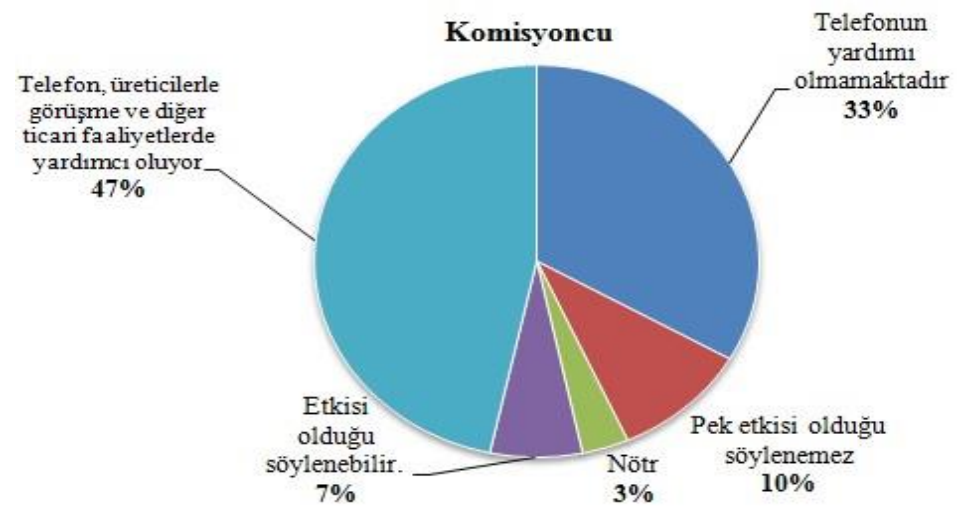

Şekil 2. Iletişim araçlarının komisyoncuların ticari faaliyetlerine etkileri.

Figure 2.The effects of communication tools on commissioners' commercial activities.

Çizelge 3. Tüccar ve komisyoncuların alıcı ve satıcılarla haberleşme oranları

Table 3. Communication rates of merchants' and commissioners' for buyers and sellers

\begin{tabular}{lclc}
\hline $\begin{array}{l}\text { Tüccar-Alıcılarla } \\
\text { Haberleşme Oranı }\end{array}$ & (\%) & $\begin{array}{l}\text { Komisyoncu-Alıcılarla } \\
\text { Haberleşme Oranı }\end{array}$ & (\%) \\
\hline Internet & 34 & Telefon & \\
Telefon & 89 & Yüz yüze & 52 \\
Yüz yüze & 23 & & \\
\hline $\begin{array}{l}\text { Tüccar- } \\
\text { Satıcılarla } \\
\text { Haberleşme Oranı }\end{array}$ & $(\%)$ & Haberleşme Oranı & $(\%)$ \\
\hline $\begin{array}{l}\text { Internet } \\
\text { Telefon }\end{array}$ & 23 & Telefon & \\
& & Yüz yüze & 65 \\
Yüz yüze & 84 & & 67 \\
\hline
\end{tabular}

\section{Sosyal ağ analizi}

Tüccarlar kendi aralarında ticari faaliyetlerinde yalnızca yüz yüze iletişimde bulunanlar, yalnızca telefon kullananlar, yalnızca internet kullananlar, bu iletişim kanallarının ikili kombinasyonlarını kullananlar ve her üçünü kullananlar olduğu görülmektedir. Ağda kurulan 44 ilişkinin \%62.2'si karşılıklı, diğer ilişkiler tekil (17) ilişki olarak kurulmuş durumdadır. Tüccarlar tarafından en çok tercih edilen iletişim aracı birinci sırada telefon, ikinci sırada internet ve üçüncü sırada yüz yüze iletişim gelmektedir. Tüccarlar arasında hem internet hem de telefon kullanımının yaygın olduğu görülmektedir (Şekil 3). Tüccarların çalıştıkları pazara yönelik kullandıkları iletişim araçlarının kullanımı farklılaşabilmektedir. Diğer ifadeyle, yurtiçinde yaş meyve ve sebze pazarlarken iletişim aracı olarak daha çok telefonu kullanmayı tercih etmekte, yurtdışına ürün pazarlarken ise internet kullanabilmektedir. Bunların yanı sıra yüz yüze ve telefon ile iletişim kurmanın yaygın olduğu söylenebilir.

Tüccarların iletişim araçları ile sağladıkları sosyal ağın yoğunluk ölçüsü \%7.5 olarak tespit edilmiştir. Bu ağda tüccarlar, kurabilecekleri iletişimin ancak \%7.5'ini kurabilmektedirler. Sosyal ağda, yoğunluk değerinin düşük olması tüccarların ticari ilişkilerinde kullandıkları iletişim aracı tercihi ya da zorunluluktan dolayı olduğu söylenebilir. 


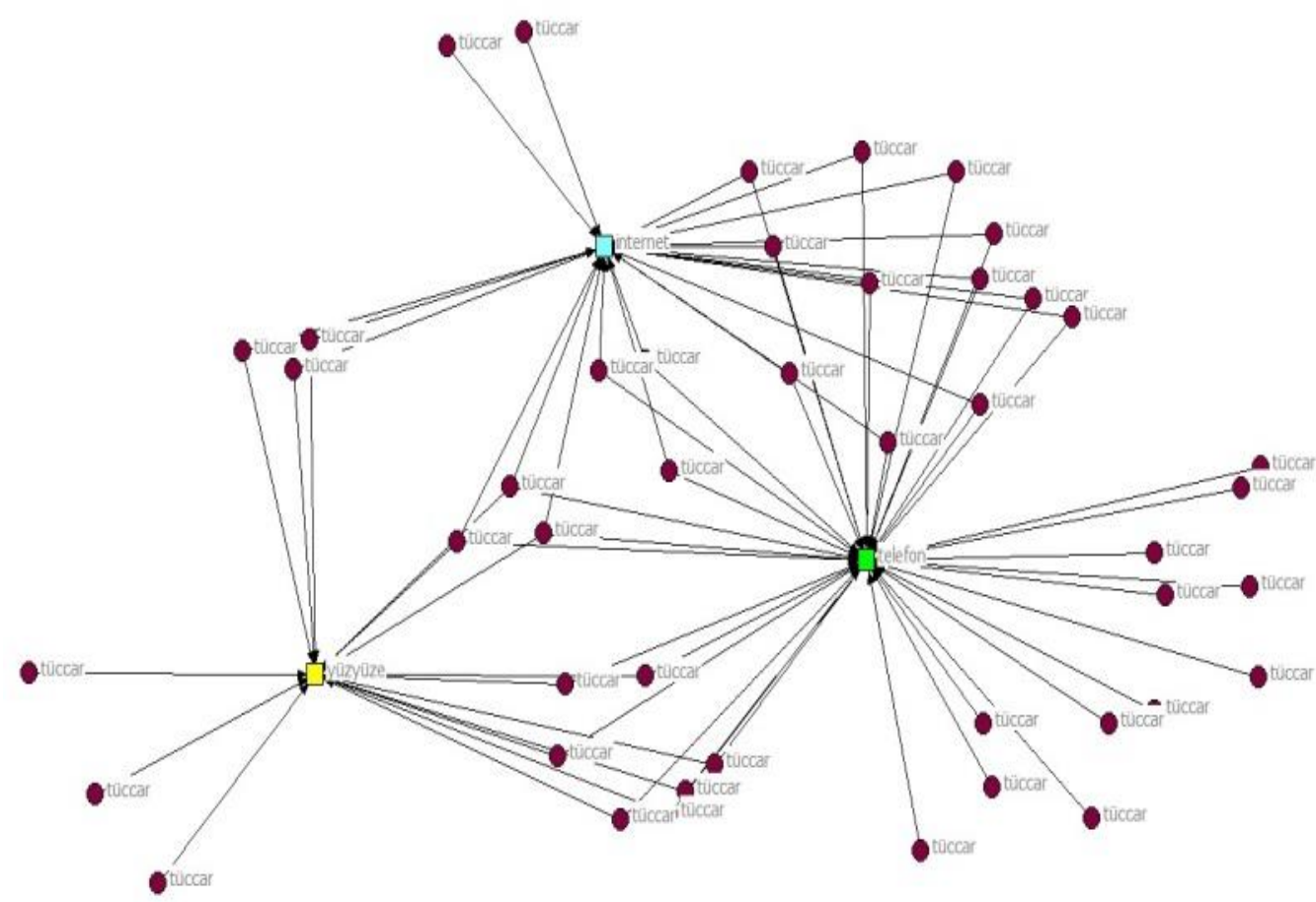

Şekil 3.Tüccarların iletişim araçları ile sağladıkları sosyal ağlar

(Sarı: Yüz yüze, Yeşil: Telefon, Mavi: İnternet) (Düğüm = 44 ; Yoğunluk = \%7.5).

Figure 3. Social networks provided by merchants via communication tools

(Yellow: Face to face, Green: Telephone, Blue: Internet) (Size = 44 node; Density = 7.5\%).

Komisyoncular kendi aralarında, çiftçilerin yaş meyve ve sebzelerini pazarlarken iletişim aracı olarak yalnızca telefon, yalnızca yüz yüze iletişim ve bu iletişim çeşitlerinin her ikisini de kullanmaktadır. Komisyoncular, ürün pazarlama faaliyetinde interneti kullanmayı tercih etmediği görülmüştür. Ağda kurulan 30 ilişkinin \%12'si karşılıklı, diğer ilişkiler tekil (18) ilişki olarak kurulmuş durumdadır (Şekil 4). Komisyoncuların önemli bir bölümü hem telefon hem de yüz yüze iletişim çeşidini kullandıkları söylenebilir.
Komisyoncuların iletişim araçları ile sağladıkları sosyal ağın yoğunluk ölçüsü \%9.6 olarak tespit edilmiştir. Sosyal ağda, yoğunluk değerinin düşük olması komisyoncuların ticari ilişkilerinde her iki iletişim aracını birlikte kullanım ihtiyacı olmamasından dolayıdır. Komisyoncular, kendi aralarında piyasa bilgisi paylaşırken telefon, ürün bilgisi paylaşırken genellikle yüz yüze görüşmeyi tercih etmektedir. Diğer yönden, ürün pazarlaması gerçekleştirirken ise her iki iletişim aracını kullandıkları görülmektedir. 


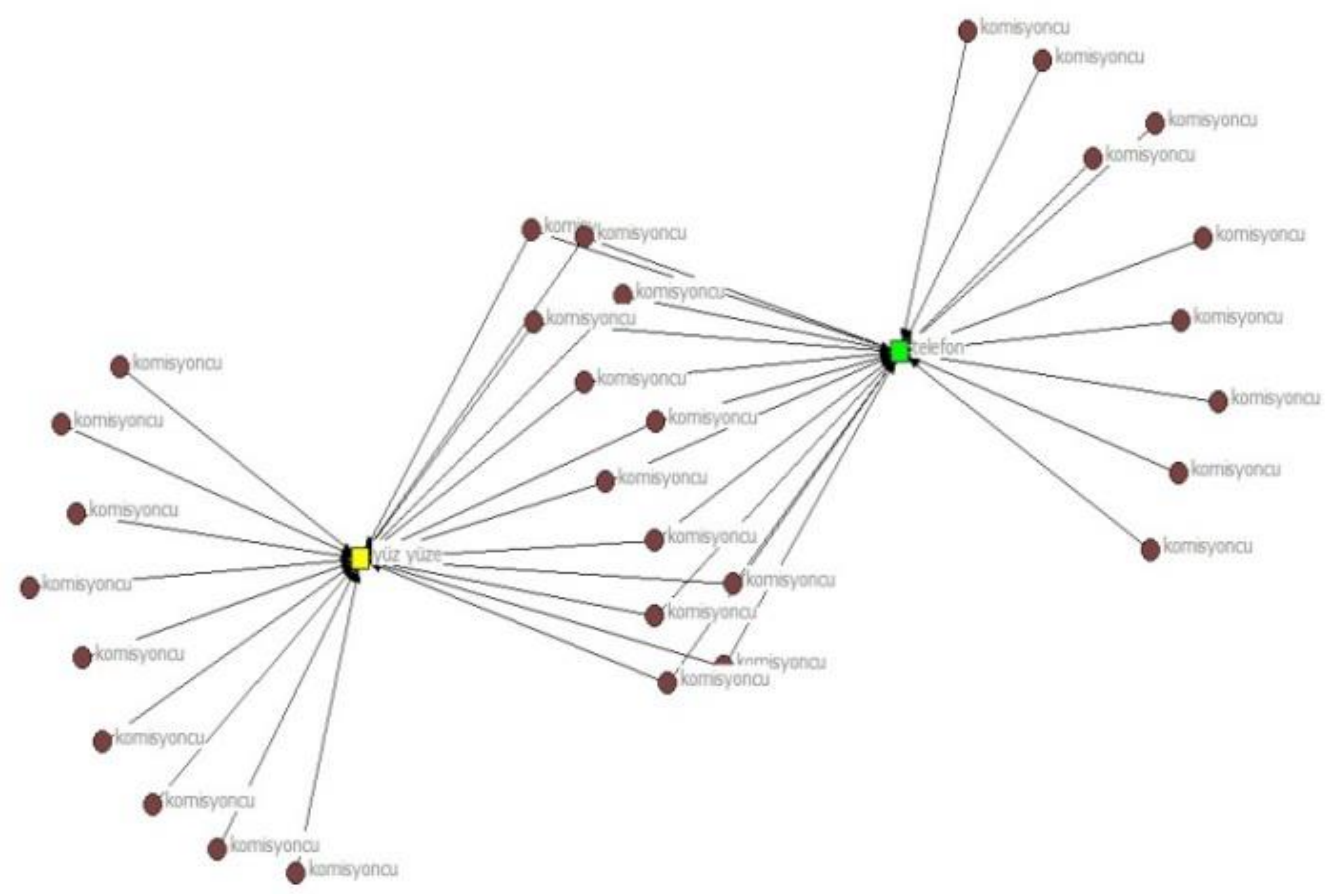

Şekil 4.Komisyoncuların iletişim araçları ile sağladıkları sosyal ağlar

(Sarı: Yüz yüze, Yeşil: Telefon) (Düğüm = 30; Yoğunluk = \%9.6).

Figure 4. Social networks provided by commissioners through communication tools

(Yellow: Face to face, Green: Telephone) (Size $=30$ node; Density $=9.6 \%$ ).

Komisyoncu ve tüccarlar arasında yaş meyve ve sebze alım satım işlemlerinde yalnızca yüz yüze, yalnızca telefon hem yüz yüze hem de telefon aracığıyla iletişim kurulduğu görülmektedir. Ağda kurulan 45 ilişkinin $\% 31^{\prime} i$ karşlıklı, diğer ilişkiler tekil (31) ilişki olarak kurulmuş durumdadır. Komisyoncu ve tüccarlar arasında iletişim aracı olarak çoğunlukla telefon kullanılmaktadır. Hem yüz yüze hem de telefon ile görüşme daha az tercih edilmektedir (Şekil 5). Yaş meyve ve sebze arz zincirinde yer alan komisyoncu ve tüccarlar arasında, piyasa bilgisi telefon ile sağlanırken ürün satışı daha çok yüz yüze gerçekleştirilmektedir.
Komisyoncu ve tüccarların iletişim araçları ile sağladıkları sosyal ağın yoğunluk ölçüsü \%4.5 olarak tespit edilmiştir. Sosyal ağda, yoğunluk değerinin düşük olması komisyoncu ve tüccarların ticari ilişkilerinde yoğun olarak telefon kullanımından kaynaklanmaktadır. Antalya Yaş meyve ve Sebze Toptancı Hali yurtiçi yaş meyve ve sebze pazarının merkezi konumunda olmasından dolayı diğer illere tüm yıl boyunca ürün göndermektedir. Komisyoncular, tüccarlara ürün pazarlarken il içinde yüz yüze görüşmeyi tercih etmekte diğer illere pazarlarken ise genellikle telefon kullanmaktadır. 


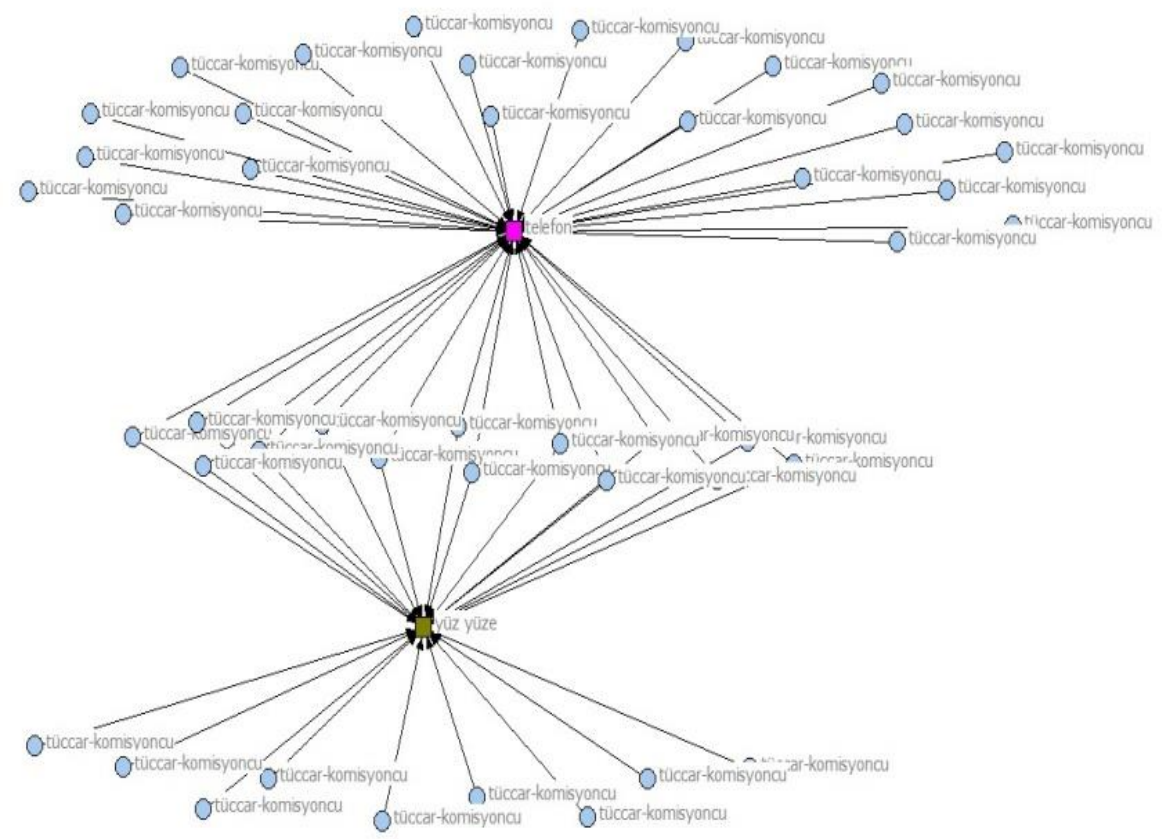

Şekil 5.Komisyoncu ve tüccarların iletişim araçları ile sağladıkları sosyal ağları (Sarı: Yüz yüze, Mor: Telefon) (Düğüm = 45; Yoğunluk = \%4.5).

Figure 5.Social networks provided by commissioners and merchants via communication tools (Yellow: Face to face, Purple: Telephone) (Size $=45$ node; Density $=4.5 \%$ )

Tüccar ve komisyoncuların sosyal ağlarının kapsamları ve sınırlııkları göz önüne alındığında, tüccarların \%59.7'sinin Toptancı Hali dışında da geniş bir ağları bulunduğu görülebilir. Aynı zamanda tüccarların \%23.4'ü ağlarının tamamen hal içiyle sınırlı olduğunu belirtmiştir.
Komisyoncuların \%76.7'lik çoğunluğu sosyal ağlarının tamamının hal içinde bulunduğu ve sınırlı olduğunu belirtmiş, böylece sosyal ağların kapsamlarının tüccarlar ve komisyoncular açısından farklılıklar gösterdiği ortaya çıkmıştır (Çizelge 4).

Çizelge 4. Komisyoncu ve tüccarların ağlarının kapsamları

Table.4. Scopes of commissioners' and merchants' networks

\begin{tabular}{lrr}
\hline Ağların Durumu & Tüccar (\%) & Komisyoncu (\%) \\
\hline Ağları tamamen hal içiyle sınırlı & 23.4 & 76.7 \\
Ağlarının çoğu hal içinde & 3.4 & 6.6 \\
Ağları hal içi ve dışı olmak üzere karışık durumda & 3.4 & 6.6 \\
Ağlarının çoğunluğu hal dışında & 10.1 & 3.4 \\
Hal dışında geniş bir ağları bulunuyor & 59.7 & 6.7 \\
Toplam & 100.0 & 100.0 \\
\hline
\end{tabular}

Sonuç olarak, Türkiye yaş meyve ve sebze ticaretinin yaklaşık \%60'ı Antalya Toptancı Hali'nde gerçekleşmektedir (Anonim, 2019). Antalya ilinden özellikle Orta Anadolu, Marmara, Karadeniz, Ege Bölgesi'nde yer alan illere ve yurtdışına birçok yaş meyve ve sebze pazarlanmaktadır. Yaş meyve ve sebze arz zincirinde yer alan aktörlerden komisyoncu ve tüccarların ticari ilişkilerinde iletişim araçları ile gerçekleştirdikleri etkileşimler sosyal ağ analizi ile açıklanmaktadır. Tüccar ve komisyoncuların sosyal ağ kapsamları ve sınırlılıkları incelendiğinde tüccarların \%60'ının Toptancı Hali dışında geniş bir ağı bulunurken sadece \%23'ünün ticari ağları tamamen Toptancı Hali içiyle sınırlı olduğu belirlenmiştir. Komisyoncuların \%77'sinin sosyal ağlarının tamamının Toptancı Hali içinde bulunduğu ve sınırlı olduğu tespit edilmiştir. Tüccarlar tarafından en çok tercih edilen iletişim aracı birinci sırada telefon, ikinci sırada internet ve üçüncü sırada yüz yüze iletişim gelmektedir. Tüccarlar arasında hem internet hem de telefon kullanımının yaygın olduğu 
belirlenmiştir. Tüccarlar, yurtiçinde yaş meyve ve sebze pazarlarken iletişim aracı olarak daha çok telefonu kullanmayı tercih etmekte, yurtdışına ürün pazarlarken ise internet kullanabilmektedir. Komisyoncuların, yaş meyve ve sebze pazarlama faaliyetinde interneti kullanmayı tercih etmediği görülmüştür. Komisyoncu ve tüccarlar arasında iletişim aracı olarak çoğunlukla telefon kullanılmaktadır. Hem yüz yüze hem de telefon ile görüşme daha az tercih edilmektedir.

Yaş meyve ve sebze ticaretinde, iletişim araçları üzerinden kurulan sosyal ağların ürünlerin pazarlanmasında önemli bir rol oynadığı açıktır. Yaş meyve ve sebze piyasasında, fiyat bilgilerinin aktarılması ve taleplerin alınmasında iletişim araçları kullanılmaktadır. İletişim araçlarının yaş meyve ve sebze piyasa fiyat oluşumunda önemli bir etkisi olduğu bilinmektedir. Çünkü komisyoncu ve tüccarlar, farklı yaş meyve ve sebze piyasalarında işlem gören ürünlerin arz ve talep durumları hakkında, sosyal ağlarının kullandığı iletişim araçlarından yararlanarak internet aracılığıyla gerçekleştirilen canlı yayın ya da telefon aracılığıyla sağlanan anlık bilgilerden faydalanarak piyasaya yönelik davranış sergilemektedir. Bu açıdan, günümüzde yaygınlaşan ve gelişen bilgi ve iletişim teknolojilerinin yaş meyve ve sebze piyasası üzerinde olumlu/olumsuz etkileri olduğu düşünüldüğünde piyasaların izlenebilirliğinin arttırılması için yaş meyve ve sebze arz zincirinde yer alan çiftçi, komisyoncu ve tüccarların bilgi ve iletişim teknolojilerinden yararlanmaları sağlanmalıdır. Bu çerçevede yaş meyve ve sebze ihracatı yapılan Avrupa Birliği ve Rusya piyasalarını takip eden dış ticaret uzmanlarının temsilciliklerde görevlendirilmelidir. Bu uzmanlar tarafından telefon ve internet aracılığıyla sürekli olarak piyasa bilgi akışı (fiyat ve arz edilen miktar) üretici bölgesi toptancı hallerine canlı iletişim kurularak sağlanmalıdır. Yurtiçi yaş meyve ve sebze piyasasının tüccar ve üreticiler tarafından takip edilebilmesi için toptancı hallerine arz edilen miktar ve fiyat bilgilerinin anlık olarak internet aracılığıyla toptancı hal kayıt sistemi web sayfalarından yayınlanması sağlanmalıdır. Böylece tüccar ve çiftçiler, internet bağlantısı bulunan cep telefonları ile piyasayı takip edebilecektir.

\section{ÖZET}

Amaç: Bu çalışmada, yaş meyve ve sebze arz zincirinde yer alan aktörlerden komisyoncu ve tüccarların ticari ilişkilerinde iletişim araçları ile gerçekleştirdikleri etkileşimler sosyal ağ analizi ile açıklanmaktadır.

Yöntem ve Bulgular: Antalya Yaş Meyve ve Sebze Toptancı Halinde faaliyet gösteren 30 tüccar ve 30 komisyoncu ile 2017 yılında yüz yüze yapılan anket verilerinden yararlanılmıştır. Tüccarların $\% 60$ 'ının Toptancı Hali dışında geniş bir ağı bulunurken sadece \%23'ünün ticari ağları tamamen Toptancı Hali içiyle sınırlı olduğu belirlenmiştir. Komisyoncuların \%77'sinin sosyal ağlarının tamamının Toptancı Hali içinde bulunduğu ve sınırlı olduğu tespit edilmiştir. Tüccarlar tarafından en çok tercih edilen iletişim aracı birinci sırada telefon, ikinci sırada internet ve üçüncü sırada yüz yüze iletişim gelmektedir. Tüccarlar arasında hem internet hem de telefon kullanımının yaygın olduğu belirlenmiştir. Komisyoncuların, yaş meyve ve sebze pazarlama faaliyetinde interneti kullanmayı tercih etmediği görülmüştür. Komisyoncu ve tüccarlar arasında iletişim aracı olarak çoğunlukla telefon kullanılmaktadır. Hem yüz yüze hem de telefon ile görüşme daha az tercih edilmektedir. Tüccar ve komisyoncuların Toptancı Halindeki sosyal ağları, yaş meyve ve sebze talebi karşılama süreçlerini kısaltmaktadır.

Genel Yorum: Yaş meyve ve sebze ticaretinde, iletişim araçları üzerinden kurulan sosyal ağların ürünlerin pazarlanmasında önemli bir rol oynadığı açıktır. Yaş meyve ve sebze piyasasında, fiyat bilgilerinin aktarılması ve taleplerin alınmasında iletişim araçları kullanılmaktadır. Illetişim araçları, yaş meyve ve sebze piyasa fiyatı oluşumunda önemli bir etkiye sahiptir.

Çalışmanın Önemi ve Etkisi: Yaş meyve ve sebze ticaretine yönelik ankete dayalı yapılan sosyal ağ çalışması bulunmamaktadır. Bu açıdan çalışmanın özgün olduğu söylenebilir. Çiftçi, komisyoncu ve tüccarların, sosyal ağlarını genişletebilmek için iletişim araçlarının etkin kullanımına yönelik strateji ve politikaların oluşturulmasına katkı sağlanması beklenilmektedir.

Anahtar Kelimeler: İletişim araçları, sosyal ağ, yoğunluk, güç yönelimli yaklaşım.

\section{TEŞEKKÜR}

Yazarlar, anketi yanıtlamayı kabul eden komisyoncu ve tüccarlara teşekkür etmektedir.

\section{ÇIKAR ÇATIŞMA BEYANI}

Makale yazarları aralarında herhangi bir çıkar çatışması olmadığını beyan ederler.

\section{ARAŞTIRMACILARIN KATKI ORANI BEYANI}

Yazarlar makaleye eşit oranda katkı sağlamış olduklarını beyan ederler.

\section{KAYNAKLAR}

Anonim (2019) Antalya Yaş meyve ve Sebze Toptancı Hal kayıtları. Antalya. $5 \mathrm{~s}$. 
Anonim (2020) Batı Akdeniz İhracatçılar Birliği Ürün Grubu Bazında îhracat Raporu. Antalya. $25 \mathrm{~s}$.

Bodin Ö, Crona BI (2009) The role of social networks in natural resource governance: what relational patterns make a difference? Global Environmental Change 19: 366-374.

Borgatti SP, Everett MG, Freeman LC (2002) Ucinet for Windows: Software for Social Network Analysis. MA: Analytic Technologies, Harvard. pp 420.

Butts CT (2008) Social network analysis with SNA. J. Stat. Softw. 24: 1-51.

Coşkun MH (2014) Aydın ilinde yaş sebze ve meyve toptancı hallerinin incelenmesi. Yüksek Lisans Tezi, Adnan Menderes Üniversitesi, Fen Bil. Enst., Tarım Ekonomisi ABD, $129 \mathrm{~s}$.

Demirtaş B, Kaya A (2018) Evaluation of Public Agricultural Extension Programs: the case of Hatay province (Turkey). Turkish Journal of Agricultural and Natural Sciences 5(2): 203-210.

DeNooy W, Mrvar A, Batagelj Vi (2011) Exploratory Network Analysis with Pajek. Structural Analysis in the Social Sciences (No. 27), Cambridge University Press, New York, USA. pp 420.

Fruchterman TMJ, Reingold EM (1991) Graph drawing by force-directed placement. Softw: Pract Exper. 21: 1129-1164.

Gürsakal N (2009) Sosyal Ağ Analizi. Dora Yayınları, Bursa. $513 \mathrm{~s}$.

Kaya A, Bostan Budak D (2021) The role and importance of vegetables in the global economy and Turkey. EJONS International Journal on Mathematic, Engineering and Natural Sciences Vol 17, ISSN: 2602-4136, 88-97.

Korum U (1981) İstatistiğe Giriş. Ankara Üniversitesi Siyasal Bilgiler Fakültesi Yayınları, Ankara. $345 \mathrm{~s}$.

Leung L (2008) Leisure boredom, sensation seeking, selfesteem, addiction symptoms and patterns of mobile phone use, Mediated Interpersonal Communication. (Eds. In E, Korini S Utz, Tanis M, Barnes S), New York: Routledge. pp 359-381.
Pan L (2007) Effective and efficient methodologies for social network analysis. PhD. Thesis, The Virginia Polytechnic Institute and State University, Computer Science and Applications, $148 \mathrm{p}$.

Przybylski AK, Murayama K, DeHaan CR, Gladwell V (2013) Motivational, emotional, and behavioral correlates of fear of missing out. Computers in Human Behavior 29: 1841-1848.

Sayın B, Akkaya F, Karaman S, Taşçıŏlu Y (2004) Antalya ilinde yaş meyve ve sebze pazarlama yapısının araştırılması. Tarım ve Köyişleri Bakanlığı, Batı Akdeniz Tarımsal Araştırma Enstitüsü, Tarım Ekonomisi Grubu, TAGEM Proje Raporu (No:1431), Antalya. $40 \mathrm{~s}$.

Scott J (2000) Social Network Analysis. SAGE Publications, London. pp 208.

Tapkı N, Kaya A, Dağıstan E, Bostan Budak D (2020) Comparison of carrot (Daucus carota L.) producing farms with regards to marketing structures, costs and applications in Hatay province. KSU J. Agric Nat 23(1): 225-233.

Tüzüntürk S (2012) Organizasyonel Ağ Analizi. Dora Yayıncılık, Bursa. $157 \mathrm{~s}$.

Wasserman S, Faust K (1994) Social Network Analysis: Methods and Applications. Cambridge University Press, New York. pp 825.

Wellman B, Berkowitz SD (1988) Social Structures a Network Approach. University Press, Cambridge. pp 526.

Yılmaz S, Yılmaz i (2002) Türkiye yaş meyve ve sebze pazarlamasında toptancı hal sisteminin değerlendirilmesi: Antalya Büyükşehir Belediyesi toptancı hali örneği. Türkiye V. Tarım Ekonomisi Kongresi, Eylül 18-20, Erzurum, Türkiye. s. 292299. 